Copyright (C) 2020 University of Bucharest Printed in Romania. All rights reserved

ISSN print: 1224-5984

ISSN online: $2248-3942$
Rom Biotechnol Lett. 2020; 25(2): 1488-1494 doi: $10.25083 / \mathrm{rbl} / 25.2 / 1488.1494$

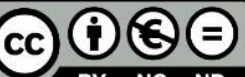

Received for publication, October, 3, 2019

Accepted, November, 4, 2019

Original paper

\title{
A new approach for phytotoxicity testing using Allium cepa bulbs
}

\author{
ADINA-DANIELA DATCU ${ }^{1}$, DANIELA-GEORGIANA CIOBANU ${ }^{1}$, BIANCA-VANESA \\ BOROS $^{1}$, VASILE OSTAFE ${ }^{1}$, IANOVICI NICOLETA ${ }^{1 *}$
}

${ }^{1}$ West University of Timisoara, Faculty of Chemistry, Biology, Geography, Department of BiologyChemistry, Pestalozzi 16, Timişoara, Romania

\begin{abstract}
This study examined the phytotoxic effects of two herbicides, glyphosate (Glifotim) and 2,4-D (DMA 6) on onion bulbs (Allium cepa). Our aim was the identification of an adequate parameter to estimate phytotoxic effects on Allium cepa bulbs directly exposed to herbicides solutions. The experiment was conducted during 2019. The short-term phytotoxic consequences on A. серa were determined after a 4-day exposure to varying concentrations of the herbicides. A gravimetric method was used for biomass (fresh, dried, organic, and mineral) determination. Eleven physiological parameters were calculated. The most sensitive parameter for all analyzed sets was relative growth rate. This parameter could represent a completion and optimization of phytotoxicity assays.
\end{abstract}

Keywords Phytotoxic effects, relative growth rate, Allium test.

To cite this article: DATCU A-D, CIOBANU D-G, BOROS B-V, OSTAFE V, NICOLETA I. A new approach for phytotoxicity testing using Allium cepa bulbs. Rom Biotechnol Lett. 2020; 25(2): 14881494. DOI: $10.25083 / \mathrm{rbl} / 25.2 / 1488.1494$

*Corresponding author: IANOVICI NICOLETA, West University of Timisoara, Faculty of Chemistry, Biology, Geography, Department of Biology-Chemistry, Pestalozzi 16, Timișoara, Romania E-mail: nicoleta.ianovici@e-uvt.ro 


\section{Introduction}

The increase in the number of xenobiotic compounds influences the environment, many of the existing chemicals representing toxicological threats to the biosphere. For ethical and economic reasons, but also due to the new laws on animal protection, the number of animal experiments should be reduced as much as possible when testing xenobiotics. The mode of action of the different substances, their long-term implications for human health, are priority scientific objectives (ȘUT,AN et al, 2014). Dramatic expansion of xenobiotic compounds through anthropic activities compromised the environment through the introduction of millions of chemical substances with toxic potential for biological systems (KRISTEN, 1997). In the last decades, numerous comparative studies were realized to evaluate toxicological effects of different herbicides classes and their risks on the environment using different plant species (KIELAK et al, 2011). JURADO et al, (2011), affirmed that when the herbicides are applied in agricultural lands, these can take different destinations due to the fact that these are degraded by microorganisms or can be transported in water far away from the de application place. Thus, organisms can be exposed to a large number of herbicides, but also to their metabolites.

For the purpose of toxicity testing of certain chemicals, higher plants represent systems suitable for a wide range of toxicological tests applicable in estimating risks to the environment and, in some cases, to vertebrates. The roots of young seedlings represent suitable testing methods, not only for the screening of pollutants, but also for the study of the mechanisms of toxic effects. Different tests, based on pollen germination and / or the test based on the growth of pollen tubes, also contributed to the understanding of the toxic action mechanisms of environmental pollutants. Other materials collected from higher plants such as segments of shoots, leaves and green seedlings, are specialized for the detection of the toxicity of chemicals that affect photosynthesis. Although these tests are not candidates for vertebrate / human toxicity testing, they are not completely insignificant in terms of testing chemicals that are toxic to the environment and indirectly to humans (DRAGOEVA et al, 2015).

Roots of cereal seedlings grown in various solutions represent a simple system for estimating the toxicity of metals in soil and water, by determining the root weight. Interactive effects of aluminum, cadmium, manganese, nickel and zinc on root growth of Triticum aestivum were analyzed as a model for plant response to metal stress and for the identification of additive, antagonistic, synergistic or multiplier interactions (TAYLOR, 1989). The inhibitory effect of herbicides for the control of Poaceae was also tracked by measuring root regeneration after root removal for Avena and of seedlings for Glycine (FEDTKE, 1987).
Fast-growing plants, such as Sinapis alba or Lactuca, have been used to test the toxic effects of benzonitrile esters, anesthetics and barbiturates (KORDAN, 1988). In addition to the inhibition of root growth, the ability to produce anthocyanins in roots and the seedling sprouting of maize showed a decrease with increasing lipid solubility due to the effects of barbiturates (KORDAN \& RENGEL, 1998).

Occasionally the coleoptiles of cereal seedlings, shoots or shoot segments, leaves from monocotyledonous and dicotyledonous seedlings were used for toxicity screening (JUNG et al, 1986; CUTLER \& JARVIS, 1985). In an early approach of phytotoxic effects examination of surfactants, the entire growth of seedlings grown in vitro was estimated by determining the weight of fresh plants after a long incubation time (150-270 days) with different concentrations of the test substance (ERNST et al, 1971). By this test, it was demonstrated that non-ionic surfactants reduce seedlings growth and viability at lower concentrations than ionic surfactants.

Of all the genotoxicity tests used over time, only the Allium test, the Tradescantia micronucleus test, and the Arabidopsis mutagenicity test were evaluated alongside the carcinogenicity tests applied to vertebrates. However, with the exception of the Arabidopsis test, the ability of these tests to predict the carcinogenic capacity was relatively low (ENNEVER et al, 1988).

The Allium test was introduced by Levan (LEVAN, 1938) to study the effects of colchicine on root growth and was then used as a standard method in the study of chromosomal aberrations (GRANT, 1982). Currently, the Allium test combines two objectives: mutagenicity and toxicity (TEDESCO \& LAUGHINGHOUSE, 2012). Toxicity is measured by observing root growth inhibition and mutagenicity is correlated with the rate of chromosome breakdown. The sensitivity of the Allium test is at the same level as, for example, testing systems that use algae or human lymphocytes. Many tests on various organisms have given similar results, comparable to the results of the Allium test, which makes this test a reliable test as a screening test (FISKESJO, 1985).

Any harmful effect has direct or indirect repercussions on root growth inhibitions (FISKESJO, 1995). In order to assess the toxicity of some compounds, standard macroscopic parameters (tumors formation, root or root tip bending and the root length) are proposed. Also, there are other indices which can be used in preliminary assays, required for the establishment of the investigated substances concentrations, like: green leaves growth restriction, turgescence and color change. Root length can be measured in two ways: normally, after the extraction from the test tube, full root length is determined using a ruler and this method gives a value for a root and allows study continuance. A more accurate method is 
represented by cutting and measuring all the roots from a bulb and this leads to the end of the experiment.

The herbicides can induce modifications on organisms that are not necessary the target, modifying ecosystem surviving and equilibrium, for both cases, aquatic and terrestrial. In this study we tested the effects of some known herbicides on Allium bulbs. Our aim was the identification of an adequate parameter to estimate phytotoxic effects on Allium cepa bulbs directly exposed to herbicides solutions.

\section{Materials and Methods}

The study was conducted in April 2019. In our experiment 50 Allium cepa bulbs were used, with an average weight of 1.6 grams. These were divided in 5 sets. The bulbs were maintained in tap water for 7 days, to form roots. In the seventh day the treatments were applied, as follows: the first set was treated with distilled water, the second was treated with an herbicide solution of DMA6, $4 \mathrm{mg} \mathrm{L}^{-1}$, the third set with DMA6, $2 \mathrm{mg} \mathrm{L}^{-1}$, the fourth set was treated with Glifotim herbicide $250 \mathrm{mg} \mathrm{L}^{-1}$ and the fifth set with Glifotim $500 \mathrm{mg} \mathrm{L}^{-1}$.

The DMA herbicide contains 2,4D dymethylamine salt in a concentration of $660 \mathrm{~g} / \mathrm{L}$. It is a systemic herbicide used in agriculture for annual and perennial dicotyledonous weed control in cereals crops (OZKUL et al, 2016).

Glifotim formulation contains glyphosate (glyphosateisopropylamine salt) in a concentration of $360 \mathrm{~g} / \mathrm{L}$. Glifotim is a total, systemic, non-selective, herbicide used in agriculture to combat annual or perennial weeds, monocotyledonous or dicotyledonous (CAREUSAGLU et al, 2011).

For the fresh biomass determination (FB), the bulbs were weighted using an analytical balance (Kern Model) in the first day of the experiment, and then reweighted in the third, the sixth and the eleventh days.

After de completion of plant exposure to treatment, the probes were dried in an oven, Sauter Model, at $100^{\circ} \mathrm{C}$, for 2 hours, to obtain plants dry biomass (DB) and water quantity (WQ). Next, the samples were introduced into a calcinator, Nabertherm model, at $500^{\circ} \mathrm{C}$, for 2 hours in order to obtain plants mineral content (MC). Organic biomass (OB) was calculated as a difference, ash content being subtracted from dry biomass.

Next, instantaneous relative growth rate $\mathrm{R}_{1}$ (between April 12 and April 15), $\mathrm{R}_{2}$ (between April 15 and April 18), $\mathrm{R}_{3}$ (between April 18 and April 22) and $\mathrm{R}_{4}$ (between April 12 and April 22) were determined. Instantaneous relative growth rate (relative growth speed, $\mathrm{g} \mathrm{g}^{-1}$ day $^{-1}$ ) can be calculated using next formula (POMMERENING and MUSZTA, 2015):

$$
R G R=\frac{\ln (W 2)-\ln (W 1)}{t 2-t 1}
$$

where $\mathrm{W} 1$ and $\mathrm{W} 2$ are dry weights at times $\mathrm{t} 1$ and $\mathrm{t} 2$.
The next physiological parameters were also determined: final growth rate, increase in fresh biomass, fresh biomass/dry biomass ratio, \% root biomass/ dry biomass, $\%$ minerals/ fresh biomass, $\%$ organic biomass from fresh biomass, \% water from fresh biomass, organic content/mineral content ratio, tissues minerals deposition (TDM=CM/DB*1000 - in $\mathrm{g} / \mathrm{kg}$ dry biomass) and tissues density ( $\mathrm{TD}=\mathrm{DB} / \mathrm{FB} * 1000$ : in $\mathrm{g} / \mathrm{kg}$ fresh biomass) (IANOVICI, 2016). Succulence was defined as the ratio between water quantity (WQ) and organic biomass (OB) (IANOVICI et al, 2012).

Analysis of variance (Kruskal-Wallis test) was realized using PAST software (HAMMER et al, 2001). $P$ values below 0.05 were considered significant.

\section{Results and Discussions}

Descriptive statistical data of the calculated physiological parameters are presented in Table 1 and 2. ShapiroWilk testing indicated that the data for gravimetric parameters and for those calculated do not have a normal distribution. Kruskall-Wallis test for medians can be considered a reserve method for ANOVA and is a nonparametric approach for comparing the probes from two or many independent groups.

Instantaneous growth rate for the plants from 2, 3, 4 and 5 sets are affected by the used herbicide concentration. After substances administration, mean values of growth rate (R3) present a significant decrease (Table 1).

Regarding final growth rates (for the entire experimental period) analysis, we noticed that there are not significant differences between the five samples sets.

Regarding the increase in fresh biomass, significant differences were observed between sets 3 and 4 ( $p=0.04854)$. Samples from the third set treated with DMA6 (2 mg/L) have the highest biomass increase at the end of the experiment (62.8925\%).

For fresh biomass/dry biomass ratio, the highest value was obtained for the fifth experimental set and the lowest for the second set, without any significant difference.

The highest percentage of root from dry biomass was calculated for the first set $(1.7422 \%)$. There are no significant differences for this parameter.

Regarding organic biomass \% and organic content/ mineral content we observed that the highest mean values were obtained for the second set treated with DMA6 (4 $\left.\mathrm{mg} \mathrm{L}^{-1}\right)$. These plants presented the lowest water percentage from fresh biomass, but also the lowest value of tissues minerals deposition. Nevertheless, the differences between the experimental values are not significant. 
Table 1. Comparative results for calculated growth rates for the five sets of probes

\begin{tabular}{|c|c|c|c|c|c|c|}
\hline & \multirow{2}{*}{$\mathrm{R}_{1}$} & \multirow[t]{2}{*}{$\mathrm{R}_{2}$} & \multirow[t]{2}{*}{$\mathrm{R}_{3}$} & \multicolumn{2}{|c|}{ Kruskal-Wallis test } \\
\hline & & & & & $\mathrm{H}$ & $\mathrm{p}$ \\
\hline \multirow{4}{*}{$\begin{array}{l}\text { set } 1 \\
\text { Control }\end{array}$} & Mean & 0.039655 & 0.048697 & 0.031394 & \multirow{4}{*}{5.128} & \multirow{4}{*}{0.07701} \\
\hline & Std. error & 0.007944 & 0.004942 & 0.005197 & & \\
\hline & Stand. dev & 0.025121 & 0.015629 & 0.016435 & & \\
\hline & Coeff. Var & 63.34882 & 32.09361 & 52.35129 & & \\
\hline \multirow[t]{4}{*}{ set 2} & Mean & 0.057424 & 0.047996 & 0.027908 & \multirow[t]{4}{*}{17.04} & \multirow[t]{4}{*}{0.0001992} \\
\hline & Std. error & 0.005211 & 0.002228 & 0.002594 & & \\
\hline & Stand. dev & 0.016478 & 0.007045 & 0.008202 & & \\
\hline & Coeff. var & 28.69508 & 14.67864 & 29.38824 & & \\
\hline \multirow[t]{4}{*}{ set 3} & Mean & 0.062502 & 0.053968 & 0.037895 & \multirow{4}{*}{6.582} & \multirow{4}{*}{0.03721} \\
\hline & Std. error & 0.008787 & 0.00467 & 0.002319 & & \\
\hline & Stand. dev & 0.024852 & 0.014011 & 0.006956 & & \\
\hline & Coeff. var & 39.76213 & 25.96145 & 18.3559 & & \\
\hline \multirow{4}{*}{ set 4} & Mean & 0.056548 & 0.049955 & 0.030133 & \multirow[t]{4}{*}{9.529} & \multirow[t]{4}{*}{0.008525} \\
\hline & Std. error & 0.011633 & 0.005494 & 0.003126 & & \\
\hline & Stand. dev & 0.026012 & 0.016483 & 0.009377 & & \\
\hline & Coeff. var & 46.00003 & 32.99623 & 31.12029 & & \\
\hline \multirow{4}{*}{ set 5} & Mean & 0.060785 & 0.053695 & 0.025934 & \multirow[t]{4}{*}{16.64} & \multirow{4}{*}{0.0008374} \\
\hline & Std. error & 0.006695 & 0.005327 & 0.00288 & & \\
\hline & Stand. dev & 0.018935 & 0.016845 & 0.009106 & & \\
\hline & Coeff. var & 31.15149 & 31.37167 & 35.11417 & & \\
\hline
\end{tabular}

Tabel 2. Comparative results for other physiological parameters calculated for the five sets of probes

\begin{tabular}{|c|c|c|c|c|c|c|c|c|}
\hline \multirow{2}{*}{\multicolumn{2}{|c|}{ Calculated physiological parameters }} & \multirow{2}{*}{$\begin{array}{c}\text { Set } 1 \\
\text { Distilled } \\
\text { water }\end{array}$} & \multirow{2}{*}{$\begin{array}{c}\text { Set } 2 \\
\text { DMA6, } 4 \\
\text { mg/L }\end{array}$} & \multirow{2}{*}{$\begin{array}{c}\text { Set } 3 \\
\text { DMA6, } 2 \\
\text { mg/L }\end{array}$} & \multirow{2}{*}{$\begin{array}{c}\text { Set } 4 \\
\text { Glifotim } 250 \\
\mathrm{mg} / \mathrm{L}\end{array}$} & \multirow{2}{*}{$\begin{array}{c}\text { Set } 5 \\
\text { Glifotim, } 500 \\
\mathrm{mg} / \mathrm{L}\end{array}$} & \multicolumn{2}{|c|}{$\begin{array}{c}\text { Kruskal- } \\
\text { Wallis test }\end{array}$} \\
\hline & & & & & & & $\mathrm{H}$ & $p$ \\
\hline \multirow[t]{4}{*}{ Final growth rate } & Mean & 0.0412 & 0.0422 & 0.0480 & 0.0363 & 0.0457 & \multirow{4}{*}{3.132} & \multirow{4}{*}{0.5359} \\
\hline & Std. error & 0.0036 & 0.0027 & 0.0043 & 0.0037 & 0.0057 & & \\
\hline & Stand. dev & 0.0108 & 0.0083 & 0.0131 & 0.0098 & 0.0182 & & \\
\hline & Coeff. var & 26.3199 & 19.7588 & 27.3457 & 27.0268 & 39.9588 & & \\
\hline \multirow{4}{*}{$\begin{array}{l}\text { Increase in fresh } \\
\text { biomass }(\%)\end{array}$} & Mean & 48.8006 & 49.4922 & 62.8925 & 41.5796 & 49.0963 & \multirow[t]{4}{*}{4.078} & \multirow[t]{4}{*}{0.3955} \\
\hline & Std. error & 5.6774 & 5.2572 & 7.1816 & 5.4332 & 6.9837 & & \\
\hline & Stand. dev & 17.9536 & 16.6248 & 21.5449 & 15.3676 & 19.7531 & & \\
\hline & Coeff. var & 36.7897 & 33.5908 & 34.2568 & 36.9595 & 40.2334 & & \\
\hline \multirow{4}{*}{$\begin{array}{l}\text { Fresh biomass/ } \\
\text { Dry biomass }\end{array}$} & Mean & 2.8739 & 2.0918 & 2.7102 & 2.754145 & 2.9702 & \multirow[t]{4}{*}{7.289} & \multirow[t]{4}{*}{0.1214} \\
\hline & Std. error & 0.5884 & 0.0820 & 0.1946 & 0.4141 & 0.3129 & & \\
\hline & Stand. dev & 1.7652 & 0.2593 & 0.6153 & 1.309584 & 0.9897 & & \\
\hline & Coeff. var & 61.4239 & 12.3983 & 22.7060 & 47.5495 & 33.3230 & & \\
\hline \multirow{4}{*}{$\begin{array}{l}\text { Root biomass } \\
\text { percentage from } \\
\text { dry biomass (\%) }\end{array}$} & Mean & 1.7422 & 1.2623 & 1.6113 & 1.3063 & 1.6827 & \multirow[t]{4}{*}{1.143} & \multirow[t]{4}{*}{0.8875} \\
\hline & Std. error & 0.4429 & 0.2039 & 0.3122 & 0.1827 & 0.3598 & & \\
\hline & Stand. dev & 1.0849 & 0.5768 & 0.8830 & 0.5168 & 1.0796 & & \\
\hline & Coeff. var & 62.2757 & 45.6980 & 54.8002 & 39.5688 & 64.1622 & & \\
\hline \multirow{4}{*}{$\begin{array}{l}\text { Minerals from } \\
\text { fresh biomass } \\
\%)\end{array}$} & Mean & 0.9037 & 0.9132 & 0.8747 & 1.0376 & 0.8672 & \multirow[t]{4}{*}{1.024} & \multirow[t]{4}{*}{0.9061} \\
\hline & Std. error & 0.1057 & 0.0994 & 0.0654 & 0.1313 & 0.0792 & & \\
\hline & Stand. dev & 0.3342 & 0.3143 & 0.2070 & 0.4152 & 0.2505 & & \\
\hline & Coeff. var & 36.9895 & 34.4216 & 23.6761 & 40.0209 & 28.8952 & & \\
\hline Organic biomass & Mean & 44.2684 & 47.6388 & 37.6643 & 39.5732 & 37.6594 & 8.211 & 0.0841 \\
\hline percentage from & Std. error & 5.1577 & 2.1540 & 2.5899 & 2.2331 & 3.0023 & & \\
\hline fresh biomass & Stand. dev & 14.5882 & 6.8116 & 8.1901 & 6.3164 & 9.0069 & & \\
\hline$(\%)$ & Coeff. var & 32.9541 & 14.2985 & 21.7450 & 15.9613 & 23.9168 & & \\
\hline Water & Mean & 60.8715 & 53.0605 & 60.2436 & 59.3768 & 61.4667 & 9.935 & 0.1393 \\
\hline percentage from & Std. error & 4.9048 & 1.559188 & 2.5865 & 2.3065 & 3.0667 & & \\
\hline fresh biomass & Stand. dev & 10.9675 & 4.6775 & 7.7596 & 6.5237 & 9.2002 & & \\
\hline (\%) & Coeff. var & 18.0174 & 8.8155 & 12.8803 & 10.9870 & 14.9678 & & \\
\hline Organic & Mean & 46.6057 & 57.8059 & 44.3986 & 42.1584 & 44.6551 & 3.03 & 0.5528 \\
\hline content/Mineral & Std. error & 6.47568 & 6.3264 & 3.2782 & 4.7831 & 3.3015 & & \\
\hline content & Stand. dev & 19.4270 & 20.0060 & 10.3665 & 13.5287 & 9.9045 & & \\
\hline & Coeff. var & 41.6838 & 34.6090 & 23.3488 & 32.0903 & 22.1800 & & \\
\hline Succulence & Mean & 1.756634 & 1.172007 & 1.649704 & 1.564675 & 1.780778 & 6.788 & 0.1475 \\
\hline & Std. error & 0.331365 & 0.069205 & 0.193696 & 0.164949 & 0.24314 & & \\
\hline & Stand. dev & 0.740954 & 0.207614 & 0.581088 & 0.466547 & 0.729419 & & \\
\hline & Coeff. var & 42.18031 & 17.7144 & 35.22379 & 29.81747 & 40.96069 & & \\
\hline TD (g/kg) & Mean & 422.9343 & 485.5203 & 385.3908 & 422.3809 & 366.6116 & 7.921 & 0.09452 \\
\hline & Std. error & 54.523 & 21.31954 & 26.14158 & 52.61856 & 33.20931 & & \\
\hline & Stand. dev & 163.569 & 67.41829 & 82.66692 & 166.3945 & 105.0171 & & \\
\hline & Coeff. var & 38.6748 & 13.88578 & 21.45015 & 39.39442 & 28.64531 & & \\
\hline TDM (g/kg) & Mean & 24.2771 & 19.2493 & 23.2758 & 26.9074 & 24.6041 & 3.641 & 0.4568 \\
\hline & Std. error & 3.1340 & 2.3898 & 1.9616 & 3.7860 & 2.2885 & & \\
\hline & Stand. dev & 9.4022 & 7.5573 & 6.2032 & 11.9725 & 7.2371 & & \\
\hline & Coeff. var & 38.7289 & 39.2603 & 26.6507 & 44.4951 & 29.4141 & & \\
\hline
\end{tabular}


Phytotoxicity assays require special attention in order to model and optimize the necessities which appear due to the influence of anthropic factors. Phytotoxicity assays represent efficient and cheap alternatives to classical toxicity tests. Research direction from the last years implies the development of some testing systems as part of a test battery in order to obtain a partial or total replacement of the experiments on vertebrates.

Allium test has multiple domains of applicability and through this known substances can be tested (e.g. for the determination of $\mathrm{pH}$ range, soluble and insoluble substances in water), but also unknown substances, generally found in tap water, natural wasters or household (FIRBAS \& AMON, 2013).

Allium test received much attention after its adaptation in soil and water pollution screening programs, for pollutants like chlorophenoxyacetic acids and chlorophenols (FISKESJO et al, 1981), aluminum (BERGGREN \& FISKESJO, 1987), heavy metal salts (LIU et al, 1995), other industrial chemical waste (FISKESJO, 1985) and pesticides (FRANEKIC et al, 1994).

Chemical products like glyphosate and 2,4 D can kill aboveground leaves, but the underground bulbs remain active and will generate new plants. In this study we have analyzed some physiological and gravimetric parameters to evaluate direct exposure effects caused by herbicides solutions on Allium cepa roots. The concentrations were chosen based on literature data. In a study, the results showed that clear negative cytogenetic effects for a $4.02 \mathrm{mg} \mathrm{L}^{-1} 2,4-\mathrm{D}$ applied $48 \mathrm{~h}$ on vegetal tissues could lead to unwanted variations that could affect genetic purity of Allium cepa (ÖZKUL et al, 2016). Other researches showed that every glyphosate dose leads to severe toxic effects on $A$. cepa cells and the most toxic effect was obtained for $500 \mathrm{mg} \mathrm{L}^{-1}$ dose. These effects induce physiological, anatomical, biochemical, cytological and genetical changes on A. сера (ÇAVUŞOĞLU et al, 2011). A significant increase of the glyphosate amount translocated from the root was observed when herbicide total absorption increased. For Zea roots, a linear relation between glyphosate concentration and absorption was noticed, in 2-30 $\mathrm{mg} \mathrm{L}^{-1}$ range (WAGNER et al, 2003).

Our results indicated an adequate parameter for the phytotoxic effects estimation on A. cepa: instantaneous relative growth rate. RGR is used on a large scale for the quantification of plant growth speed (HOFFMANN and POORTER, 2002). RGR represents the increase of plant size when compared with the same plant, in a given time interval. We calculated RGR using fresh biomass values of the same plant, in three distinct moments, without a destructive approach.

RGR was used to express the effect of fertilizers, weed control, shadow, soil humidity carbon dioxide, sulphur dioxide and ozone on growth.

Relative growth rate is also used to compare the differences caused by genotype and seedlings size. This technique can be seen as a valuable method when comparing seedlings with different sizes. Relative growth rates examination is a major indicator of productivity plant strategies in a stressing and disturbed environment (KARADAVUT et al, 2010), like in our experiment due to herbicide use. Herbicide concentrations significantly affected the growth rate of Allium cepa bulbs. We consider that this parameter can be successfully included in phytotoxicity assays of different xenobiotics using Allium test.

This study was carried out within the project PATCULT \# RO (PN-III-P1-1.2-PCCDI-2017-0686), which is funded by UEFISCDI - Romania.

\section{Conclusions}

The aim of the present study was to evaluate toxicity induced by glyphosate and 2,4-D in A. cepa. Two different doses of both Glifotim ( 250 and $500 \mathrm{mg} \mathrm{L}^{-1}$ ) and DMA 6 ( 2 and $4 \mathrm{mg} \mathrm{L}^{-1}$ ) were applied. Physiological parameters could be relatively quickly and cheaply evaluated by Allium test. Relative growth rate gives very important data about plant growth and is the most important index of productivity. This physiological parameter could represent a completion and optimization of phytotoxicity assays.

\section{References}

1. AMER SM, ALY FA. Genotoxic effect of 2,4-dichlorophenoxy acetic acid and its metabolite 2,4-dichlorophenol in mouse. Mutat Res. 494(1-2):1-12 (2001).

2. BARILE FA. Introduction to In Vitro Cytotoxicology: Mechanisms and Methods. Boca Raton: CRC Press, p. 222 (1994).

3. BERGGREN D, FISKESJO G. Aluminum toxicity and speciation in soil liquids-experiments with Allium cepa $\mathrm{L}$. Environmental and Toxicological Chemistry. 6:771-779 (1987).

4. ÇAVUŞOĞLU K, YALÇIN E, TÜRKMEN Z, YAPAR K, ÇAVUŞOĞLU K, ÇIÇEK F. Investigation of Toxic Effects of the Glyphosate on Allium cepa. Tarım Bilimleri Dergisi - Journal of Agricultural Sciences, 17: 131-142 (2011).

5. CLEMEDSON C, MCFARLANE-ABDULLA E, ANDERSSON $M$, BARILE FA, CALLEJA MC, CHESNE C, CLOTHIER R, COTTIN M., CURREN R, DIERICKX P, FERRO M, FISKESJO G., GARZAOCANAS L, GOMEZ-LECHON ML, GULDEN M, ISOMAA B, JANUS J, JUDGE P, KAHRU A, KEMP RB, KERSZMAN G, KRISTEN U, KUNIMOTO M, KARENLAMPI S, LAVRIJSEN K, LEWAN L, LILLIUS H, MALMSTERN A, OHNO T, PERSOONE G, PETTERSSON R, ROGUET R, ROMERT L, SANDBERG M, SAWYER TW, SEIBERT $H$, SHRIVASTAVA R, SJOSTROM M, STAMMATI A, TANAKA N, TORRES-ALINIS O, VOSS JU, WAKURI S, WALUM E, WANG X, ZUCCO F, EKWALL B. MEIC evaluation of acute systemic toxicity. 
Part II. In vitro results from 68 toxicity assays used to test the first 30 reference chemicals and comparative cytotoxicity analysis. ALTA. 24(1):273-311 (1996).

6. CUTLER HG, JARVIS BB. Preliminary observations on the effects of macrocyclic trichotecenes on plant growth. Environmental and Experimental Botany. 25: 115-128 (1985).

7. DRAGOEVA AP, KOLEVA VP, NANOVA ZD, GEORGIVE BP. Allelopathic Efffects of Adonis vernalis L.: Root Growth Inhibition and Cytogenetic Alterations. Journal of Agricultural Chemistry and Environment. 4: 48-55 (2015).

8. ENNEVER FK, ANDREANO G, ROSENKRNAZ HS. The ability of plant genotoxicity assays to predict carcinogenicity. Mutation Research. 205:99-105 (1988).

9. ERNST R, ARDITTI J, HEALEY PL. Biological effects of surfactans. I. Influence on the growth of the orchid seedlings. New Phytologist. 70:457-475 (1971).

10. FAUSTINI A, SETTIMI L, PACIFICI R, FANO V, ZUCCARO P, FORASTIERE F. Immunological changes among farmers exposed to phenoxy herbicides: preliminary observations. Occup Environ Med. 53(9): 583585 (1996).

11. FAYEZ KA, GERKEN I, KRISTEN U. Ultrastructural responses of root caps to the herbicides chlorsulfuron and metsulfuron methyl. Plant and Soil. 167:127-134 (1994).

12. FAYEZ KA, KRISTEN U. The influence of herbicides on the growth and proline content of primary roots and on the ultrastructure of root caps. Environmental and Experimental Botany. 36:71-81 (1996).

13. FEDTKE C. Physiological activity spectra of existing graminicides and the new herbicide 2-(2-benzothiazolyl-oxy)-N-methyl-N-phenylacetamide (megenacet). Weed Research. 27:221-228 (1987).

14. FIRBAS P, AMON T. Allium Chromosome Aberration Test for Evaluation Effect of Cleaning Municipal Water with Constructed Wetland (CW) in Sveti Tomaž, Slovenia. Journal of Bioremediation \& Biodegradation. 4(4) (2013).

15. FISKESJO G. The Allium test as a standard in environmental monitoring. Hereditas. 102: 99-112 (1985).

16. FISKESJO G. The Allium Test in Wastewater Monitoring. Environmental Toxicology and Water Quality: An International Journal. 8:291-298 (1993).

17. FISKESJO G. Allium Test II: Assessment of a Chemical's Genotoxic Potential by Recording Aberrations in Chromosomes and Cell Divisions in Root Tips of Allium cepa L. Environmental Toxicology and Water Quality: An International Journal. 9:245-241 (1994).

18. FISKESJO G. Allium Test, pp. 119-127. In: In vitro Testing Protoclos. O'Hare S., Atterwill C.K. (eds.), Humana Press Inc, Totowa, NJ (1995).

19. FISKESJO G, LASSEN C, RENBERG L. Chlorophenoxuacetic acids and chlorophenols in the modified Allium test. Chemico-Biological Interactions. 34:333344 (1981).

20. FLABURIARI A, KRISTEN U. The influence of chlorsulfuron and metsulfuron methyl on root growth and on the ultrastructure of root tips of germinating maize seeds. Plant and Soil. 180:19-28 (1996).

21. FRANEKIC J, BRATULIC N, PAVLIKA M, PAPES D. Genotoxicity of thiocarbamates and their metabolites. Mutation Research. 325:65-74 (1994).

22. FUKUYAMA T, TAJIMA Y, UEDA H, HAYASHI K, SHUTOH Y, HARADA T, KOSAKA T. Allergic reaction induced by dermal and/or respiratory exposure to low-dose phenoxyacetic acid, organophosphorus, and carbamate pesticides. Toxicology 261(3):152-61. doi: 10.1016/j.tox.2009.05.014 (2009).

23. GRANT WF. Chromosome aberration assays in Allium. A report of the U.S. Environmental Protection Agency Gene-Tox Program. Mutation Research. 99: 273-291 (1982).

24. HOFFMANN WA, POORTER H. Avoiding bias in calculations of Relative Growth Rate. Annals of Botany. 90 (1): 37-42. doi:10.1093/aob/mcf140 (2002).

25. HAMMER $\varnothing$, HARPER DAT., RYAN PD. PAST: Paleontological Satistics software package for education and data analysis. Paleontologica Electronica. 4 (1): 1-9 (2001).

26. IANOVICI N, CIOCAN GV, MATICA A, SCURTU M, SESAN TE. Study on the infestation by Cameraria ohridella on Aesculus hippocastanum foliage from Timisoara, Romania. Annals of West University of Timişoara, ser. Biology. 15(1): 67-80 (2012).

27. IANOVICI N. Taraxacum officinale (Asteraceae) in the urban environment: seasonal fluctuations of plants traits and their relationship with meteorological factors. Acta Agrobotanica. DOI: 10.5586/aa.1677 (2016).

28. JUNG J, RENTZEA C, RADEMACHER W. Plants growth regulation with triazoles of the dioxanyl type. Journal of Plant Growth Regulation. 4:181-188 (1986).

29. JURADO AS, FERNANDES MAS, VIDEIRA RA, PEIXOTO FP, VICENTE JAF. Herbicides: The Face and the Reverse of the Coin. An in vitro Approach to the Toxicity of Herbicides in Non-Target Organisms. In: KORTEKAMP, A. (Ed.) Herbicides and Environment. Kroatia, pp. 3-45 (2011).

30. KANDASAMY MK, KRISTEN U. Influence of triethyllead on growth and ultrastructure of tocacco pollen tubes. Environmental and Experimental Botany. 29:283-292 (1989).

31. KARADAVUT U, KOKTEN K, KAVURMACI Z. Comparison of Relative Growth Rates in Silage Corn Cultivars. Asian Journal of Animal and Veterinary Advances. 5 (3): 223-228 (2010).

32. KIELAK E, SEMPRUCH C, MIODUSZEWSKA H, KLOCEK J, LESZCZYŃSKI B. Phytotoxicity of Roundup Ultra 360 SL in aquatic ecosystems: Biochemical evaluation with duckweed (Lemna minor L.) as a model plant. Pestic Biochem Physiol. 99(3):237-243 (2011).

33. KORDAN HA. Barbiturate effects on germinating plant seedlings. ATLA. 15:251-254 (1988).

34. KORDAN HA, RENGEL Z. Impaired anthocyanin production in barbiturate-treated Zea mays seedlings. Annals of Botany. 61:221-223 (1998). 
35. KRISTEN U. Main features of basal cytotoxicity: sites of toxic action and interaction in the pollen tube cell. ATLA. 24:429-434 (1996).

36. KRISTEN U. Use of Higher Plants as Screens for Toxicity Assessment. Toxicology in Vitro. 11: 181-191 (1997).

37. KRISTEN U. Use of higher plants as screens for toxicity assessment. Toxicology in vitro, United Kingdom, v. 11, p. 181-191 (1997).

38. LEVAN A. The effect of colchicine on root mitoses in Allium. Hereditas. 24:471-486 (1938).

39. LIU D, JIANG W, WANG W, ZHAI L. Evaluation of metal ion toxicity on root tip cella by the Allium test. Israel Journal of Plant Science. 43:125-133 (1995).

40. LOWE KC, DAVEY MR, POWER JB, CLOTHIER RH. Plants as toxicity screens. Pharmaceutical News, 2:17-22 (1995).

41. MA TH. Tradescantia cytoogenetic tests (root tip mitosis, pollen mitosis, pollen mother cells). Mutation Research. 99:293-302 (1982).

42. MA TH, HARRIS MM, VAN ANDERSON A, AHMED I, MOHAMMAD K, BARE JL, LIN G. Tradescantia-micronucleus (Trad-MCN) test on 140 health-related agents. Mutation Research. 138:157-167 (1984).

43. MARTINI CN, GABRIELLI M, VILA MDC. A commercial formulation of glyphosate in- hibits proliferation and differentiation to adipocytes and induces apoptosis in 3T3-L1 fibroblasts. Toxicology in Vitro, v. 26, p. 1007-1013 (2012).

44. MOSINGER B, REDDING KM, PARKER MR, YEVSHAYEVA V, YEE KK, DYOMINA K, LI Y, MARGOLSKEE RF. Genetic loss or pharmacological blockade of testes-expressed taste genes causes male sterility. Proc Natl Acad Sci (PNAS) USA. doi/10.1073/ pnas.1302827110 (2013).

45. O'HARE S, ATTERWILL CK (eds.). In Vitro Testing Protocols. Methods in Molecular Biology. Vol. 43. Humana Press, Totowa, NJ, p. 332 (1995).

46. OGELEKA DF, OKIEIMEN FE, EKPUDI FO, TUDARARO-AHEROBO LE. Short-term phytotoxicity consequences of a nonselective herbicide glyphosate (Roundup $^{\mathrm{TM}}$ ) on the growth of onions (Allium cepa Linn.). African Journal of Biotechnology. 15 (18): 740-744 (2016)

47. ÖZKUL M, ÖZEL CA, YÜZBAŞIOĞLU D, ÜNAL F. Does 2,4-dichlorophenoxyacetic acid (2,4-D) induce genotoxic effects in tissue cultured Allium roots? Cytotechnology. 68(6): 2395-2405 (2016).

48. PARK K, PARK J, KIM J, KWAK IS. Biological and molecular responses of Chironomus riparius (Diptera, Chironomidae) to herbicide 2,4-D (2,4-dichlorophenoxyacetic acid). Comp Biochem Physiol C Toxicol Pharmacol. May; 151(4):439-46. doi: 10.1016/j.cbpc.2010.01.009 (2010).
49. PHAM TH, DERIAN L, KERVARREC C, KERNANEC PY, JÉGOU B, SMAGULOVA F, GELY-PERNOT A. Perinatal Exposure to Glyphosate and a Glyphosate-Based Herbicide Affect Spermatogenesis in Mice, Toxicological Sciences, 169 (1): 260271, https://doi.org/10.1093/toxsci/kfz039 (2019).

50. RODERER G, REISS HD. Different effects of inorganic and triethyl lead on growth and ultrastructure of lily pollen tubes. Protoplasma. 144:101-109 (1988).

51. RODRIGUEZ EM, SCHULDT M, ROMANO L. Chronic histopathological effects of parathion and 2,4-D on female gonads of Chasmagnathus granulata (Decapoda, Brachyura). Food \& Chemical Toxicology 32(9):811-818 (1994).

52. RUBIN JL, GAINES CG, JENSEN RA. Enzymological basis for herbicidal action of glyphosate, Plant Physiology, 70: 833-839 (1982).

53. SAWIDIS T, REISS HD. Effects of heavy metals on pollen tube growth and ultrastructure. Proroplasma. 185:113-122 (1995).

54. SOLOMON KR, THOMPSON DG. Ecological risk assessment for aquatic organisms from over-water uses of glyphosate, J. Toxicol. Environ. Health B Crit. Rev. 6(3): 289-324 (2003).

55. SZEPANOWSKI F, KLEINSCHNITZ C, STETTNER M. Glyphosate-based herbicide: a risk factor for demyelinating conditions of the peripheral nervous system? Neural Regen Res, 14 (12): 2079-2080 (2019).

56. ȘUT,AN NA, POPESCU A, MIHĂESCU C, SOARE LC, MARINESCU MV. Evaluation of cytotoxic and genotoxic potential of the fungicide Ridomil in Allium cepa L. Analele Științifice ale Universității „Al. I. Cuza” Iaşi s. II a. Biologie vegetală. 60, 1: 5-12 (2014).

57. TAYLOR GJ. Multiple metal stress in Triticum aestivum: differentiation between additive, multiplicative, antagonistic and synergisitc effects. Canadian Journal of Botany. 62:2272-2276 (1989).

58. TEDESCO SB, LAUGHINGHOUSE HD. Bioindicator of genotoxicity: the Allium cepa test. Environmental contamination, p. 137-156 (2012).

59. TORRETTA V, KATSOYIANNIS IA, VIOTTI P, RADA EC. Critical Review of the Effects of Glyphosate Exposure to the Environment and Humans through the Food Supply Chain. Sustainability, 10, 950; doi:10.3390/su10040950 (2018).

60. UNDERBRINK AG, SCHAIRER LA, SPARROW AH. Tradescantia stamen hairs: a radiobiological test system applicable to chemical mutagenesis. In Chemical Mutagenesis: Principles and Methods for their Detection. Hollaender A. (ed.), vol. 3. Plenum Press, New York (1973).

61. WAGNER R., KOGAN M., PARADA A.M. Phytotoxic activity of root absorbed glyphosate in corn seedlings (Zea mays L.), Weed Biology and Management 3: 228-232 (2003). 